\title{
Influence of artificial tides in Ucides cordatus innate immune system
}

\author{
Gisele de Aquino Prado da Costa ${ }^{I}$, Ariane Teixeira Bertoldi ${ }^{l}$, Douglas de Sousa Costa ${ }^{1}$, Vivian \\ Ribeiro Pimentel ${ }^{1}$, Juliano de Oliveira Barbirato ${ }^{I}$, Leonardo Barros Dobbss ${ }^{1}$, Cláudio Romero \\ Farias Marinho ${ }^{1}$, Carlos Eduardo Tadokoro ${ }^{1 *}$
}

\author{
${ }^{1}$ Universidade Vila Velha - Laboratório de Imunobiologia \\ (R. José Mauro de Vasconcelos, s/n - 29107-530 - Vila Velha - ES, Brazil) \\ *Corresponding author: carlos.tadokoro@uvv.br
}

Mangroves protect coastal lines, act as a biogeochemical barrier against pollutants, and function as husbandries for life cycles of many species, including the mangrove crab Ucides cordatus. The population distribution of these crabs extends from Florida, USA, to the southern coast of Brazil, where this species inhabits the intertidal zone and each animal digs its own hole in the sediment (CONTI; NALESSO, 2010; GOES et al., 2010; SANT'ANNA et al., 2014). This crab species is one of the main processors of leaf litters in mangroves, optimizing energy transfer and nutrient cycling (NORDHAUS; WOLFF, 2007), and making U. cordatus a keystone species within the ecosystem (SCHORIES et al., 2003).

$U$. cordatus in estuarine regions of Brazil, including the northern most part of Southeast Brazil and the Northeast regions, has a relevant economic importance as a fishery resource for the local population (GLASER; DIELE, 2004; LEITE et al., 2013). To minimize the impact of crab over-exploitation, this fishery is selective, where females and/or individuals with a cephalothorax width less than six centimeters are rejected (PASSOS; BENEDITTO, 2005). However, despite the implementation of these conservation measures, $U$. cordatus populations have been decreasing in many Brazilian coastal zones (DIELE et al., 2005).

Studies of $U$. cordatus have been carried out by harvesting crabs in different areas and seasons, mostly to evaluate the environmental impacts on crab populations (MIGUEL et al., 2007), or to measure the presence of crab contamination with pathogenic agents that could

Submitted on: 14/July/2016

Approved on: 28/June/2017

http://dx.doi.org/10.1590/S1679-87592017131606503 represent a risk for human consumption (VIEIRA et al., 2004). Some of these studies are also used to evaluate the impact of environmental contamination by searching for the presence of chemical compounds or microorganisms within the $U$. cordatus population (CORRÊA JUNIOR et al., 2000; ORÉLIS-RIBEIRO et al., 2011; PIE et al., 2011; PINHEIRO et al., 2012; VICENTE et al., 2012; VILHENA et al., 2013). Some studies have attempted to mimic the environmental conditions in natural fisheries by adding a gravel ramp to allow animals to move in-or-out the water (SANTOS, 2002; LEITE; ZANOTTO, 2013). Among these studies with captive crabs, the influence of tidal cycles in animal physiology was not considered. However, such exogenous factors are important considering that $U$. cordatus lives in variable salinity environments that affect the calcium transport in gill cells (LEITE; ZANOTTO, 2013), and reproduction behavior (SANT'ANNA et al., 2014). Crab and prawns have an innate immune system formed by proteins and cells present in their hemolymph (MILLAR; RATCLIFFE, 1994). Three cell types are found in the hemolymph of these animals: granular (G), semigranular (SG), and hyaline $(H)$ cells (SMITH; SÖDERÄLL, 1983). After injury or disease, the prophenoloxidase activating system (proPO) enters in action. The proPO system is localized inside circulating hemocytes and is exocytosed after cellular stimulation with microorganism compounds (SÖDERHÄLL; CERENIUS, 1992). Semigranular and granular cells are responsible for storage of the proPO system and can exert cytotoxic effects in target cells, while hyaline and semigranular cells are capable of phagocitosis 
(JOHANSSON et al., 2000). Therefore, counting of each cell type in crab hemolymph can be used to characterize the innate immune response inside $U$. cordatus. To our knowledge, no published results exist that elucidate the amount of variations of hemocyte types according to different $U$. cordatus husbandry systems.

To mimic natural environmental mangrove conditions inside our lab, we developed a new tank system consisting of mangrove sediment together with a water pump. The pump was used to recreate mangrove tide differences throughout the period of a day. Details of this tank system (experimental tank) are shown in Figures 1 and 3. We also constructed and installed conventional tanks published by others in order for comparison of water salinity between these systems and our new tank system (Figures 2 and 3).
Our experimental tank system was capable of mimicking two high and low tides per day. To achieve this we controlled two parameters: filling and pouring rates. The filling rate was defined as the amount of water pumped from a reservoir into the tank where all animals were confined; the pouring rate was defined as the amount of water leaking from our tank towards the reservoir. The filling rates were controlled by connecting our water pump to a timer and allowing it to turn on and off every 6 hours. Pouring rates were controlled by the size of our tubes since water exited from our tank to the reservoir by gravity. The two rate parameters needed to be synchronized for proper functioning: first, the filling rates had to be twice the pouring rates, otherwise there would be no tank filling (high tide); second, the pouring rates could not stop before
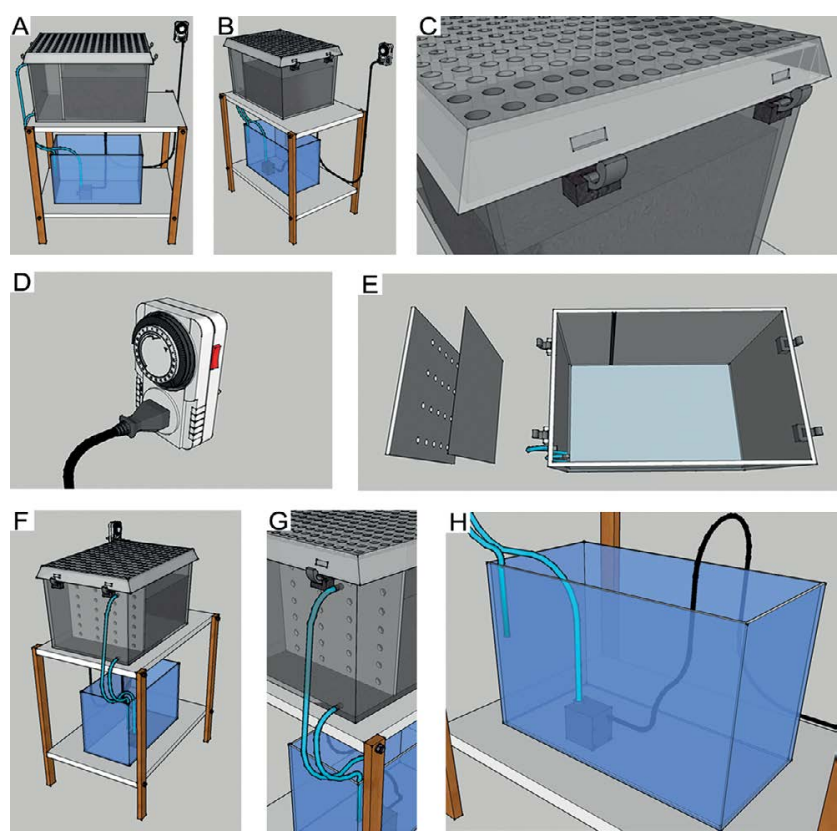

Figure 1. Design of new experimental tank to mangrove crabs. This crab tank was designed and developed to simulate natural mangrove tides within the lab. (A), front view of our experimental tank, showing a plastic cage on top (where $U$. cordatus are kept) and a glass cage on bottom (where water from top cage is storage to be reused during the next "high" tide period); (B), lateral view of our system; (C) cover of our plastic cage showing all holes to allow cage ventilation and two brackets to clamp this cover to the plastic cage; (D), water pump plug connected to a timer to allow this pump to gradually fill our plastic cage for $6 \mathrm{~h}$; (E), inside details of top plastic cage, showing a plastic division that was hot glued to the cage at the black line. A $0.7 \times 0.7$ $\mathrm{mm}$ mesh just at the left of this plastic division is used to minimize sediment lost to the bottom glass cage; $(\mathrm{F})$, lateral view showing two tubing connections to allow water coming in and out of the top plastic cage; $(\mathrm{G})$, close detail of these tubing connections, where the one on the top side brings water from the bottom glass cage back to the top plastic cage throughout a water pump. The bottom tube allows water to drop from the top plastic cage to bottom glass cage. Standard silicon tubes (5 $\mathrm{mm}$ diameter) were used to connect tanks.; $(\mathrm{H})$, details of the bottom glass cage showing a water pump which forces the water back to the top plastic cage. Water salinity was changed and equalized together with mangrove sediment; each salinity was measured by an EcoSense EC300 conductivity meter (YSI Life Sciences, USA). Water temperature was maintained at $23{ }^{\circ} \mathrm{C}$ and monitored by a thermometer. 

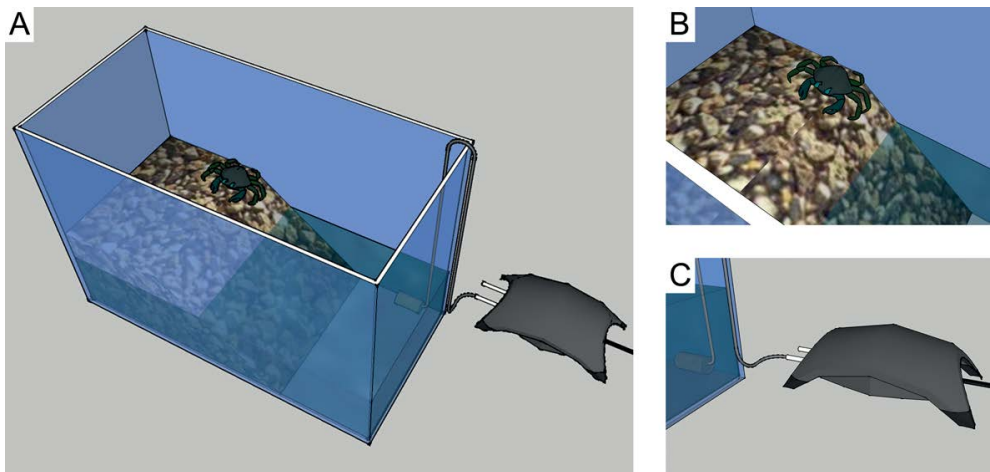

Figure 2. A conventional crab cage. Traditionally, $U$. cordatus are kept within the lab in a glass cage (A) with a gravel ramp, salt water, and an air pump. (B), if animals need to be outside water they climb this gravel ramp; (C) detail of an air pump connected to an aerator stone to oxygenate water inside the tank. Water salinity was changed and equalized together with gravel; each salinity was measured by an EcoSense EC300 conductivity meter (YSI Life Sciences, USA). Water temperature was maintained at $23^{\circ} \mathrm{C}$ and monitored by a thermometer.
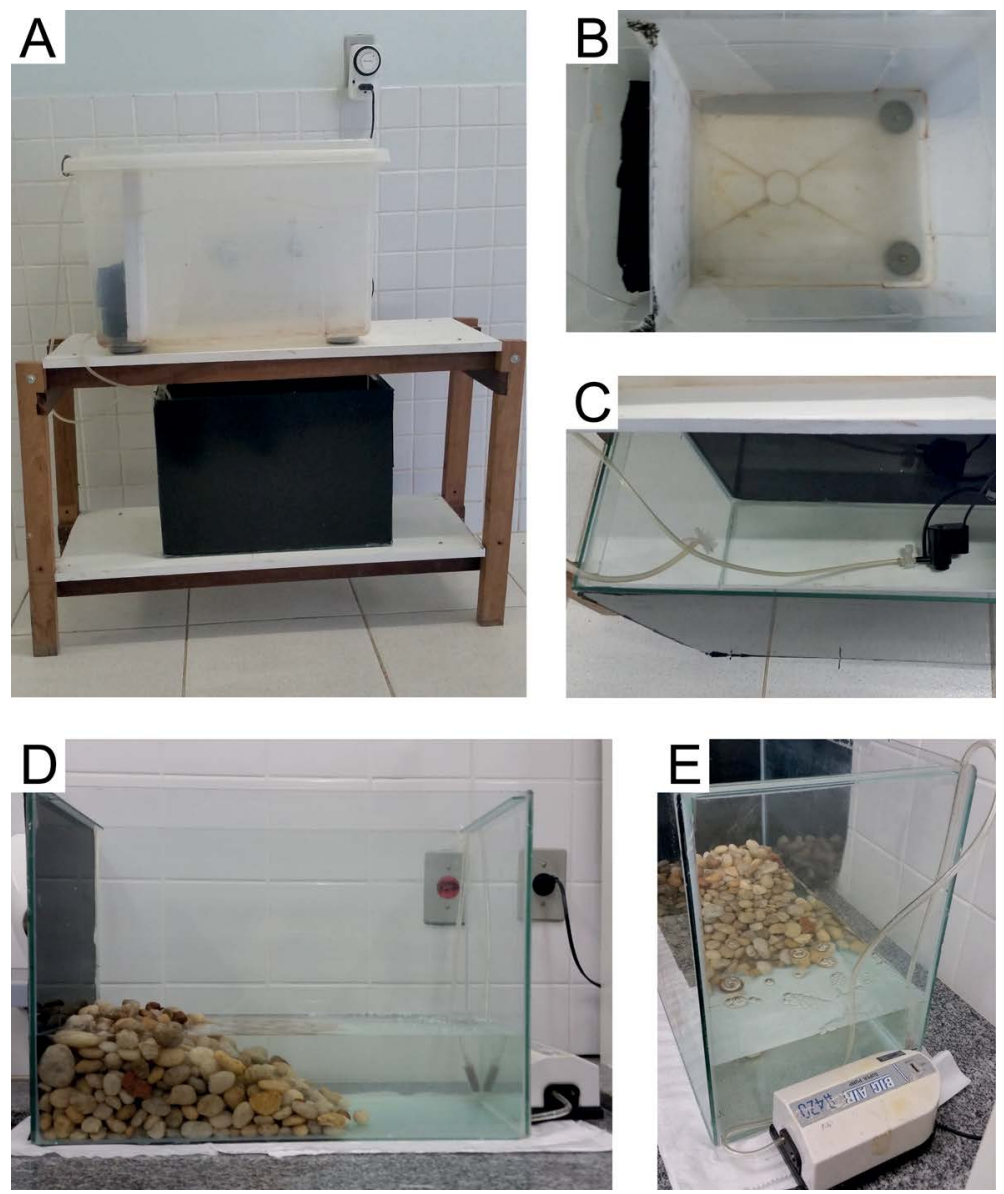

Figure 3. Experimental (A, B, C) and conventional (D, E) tanks for $U$. cordatus husbandry. The whole experimental system containing one tank where animals are kept (top white box) and one tank (bottom black box) where water is stored during "low tides"; (B), the inside details of the top white box, showing a plastic division to avoid sediment in the bigger compartment (right side) to clog water tubes inside the smaller compartment (left side); (D), conventional tanks have only a gravel ramp where crabs go inside/outside water, according to their convenience; (E), conventional tank detail showing an air pump constantly providing air to that system. 
$6 \mathrm{~h}$ of leaking, otherwise periods of low and high tides will be different. Since pump characteristics are different depending upon the manufacturer, we conducted a series of tests of the water pump during the time dedicated to mount the whole system.

Another important factor that was considered was the amount of water used to cover the sediment during the high tide. This water column needed to be between 10 to 15 centimeters. In our system, we used a $100 \mathrm{~L}$ plastic box and at least $24 \mathrm{~L}$ of water in order to fill the entire box during high tides.

Finally, despite the use of meshes and sponges to avoid obstruction of tubes, mangrove sediment is rich in organic matter and causes the tubes of the system to clog over the time. Therefore, constant checking of tubing was necessary to avoid any disruption of tide times and volumes. When necessary, the tubes and meshes were changed to avoid future tide problems.
We found that it is also recommendable to perform a full pump washing in tap water every two days.

Since our experimental system simulates an important environmental condition (different "tides" during the day), we checked whether this would interfere with a physiological parameter, in our case the amount of cell types in hemolymph.

As shown in Figure 4A, the variation of semigranular and hyaline cell types were higher in animals kept in our experimental tank than crabs kept in a conventional tank when water salinities were maintained at $10 \mathrm{ppt}$. Since semigranular and hyaline cells are important to innate immune cells for phagocitosis (JOHANSSON et al., 2000), it is possible that tide variations can interfere with this process and these animals could present a different immunity during the day. If this were the case, $U$. cordatus would be more susceptible to natural or anthropic environmental alterations at different times of the day.

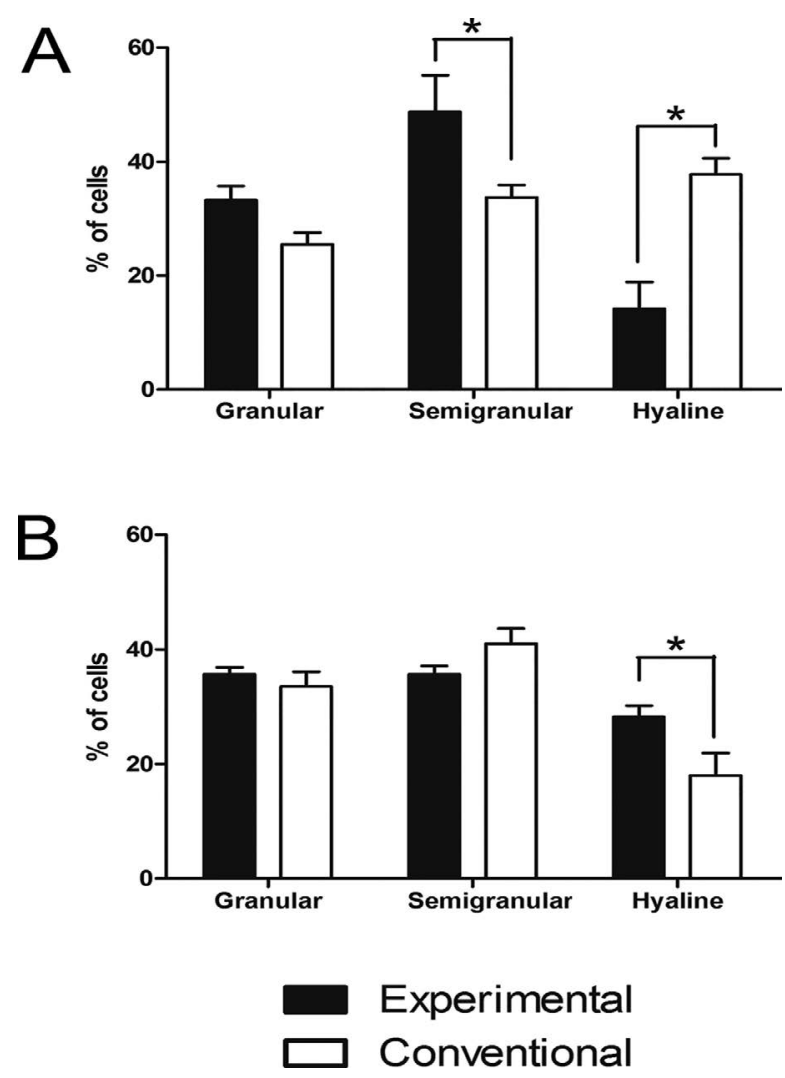

Figure 4. Counting of hemocytes from crabs kept in experimental and conventional tanks. (A) Results from animals kept at $10 \mathrm{ppt}$; (B) Results from animals kept at $24 \mathrm{ppt}$. All animals were cold anesthetized before hemolymph harvesting. After fixation and staining, each sample was counted and these results represent average and standard deviation from 4 to 6 animals. These results are representative of 2 independent experiments. A total of 72 crabs were used in our experiments. Two-way ANOVA with Bonferroni post test were performed to determine significant differences between the groups in our experimental study. These tests yielded $p$ values $<0.05$, which confirmed the statistical significance of our results. 
At $24 \mathrm{ppt}$, animals kept in the experimental tanks showed higher levels of only hyaline cells (Figure 4B). Taken together with previous differences in semigranular and hyaline cells at $10 \mathrm{ppt}$ (Figure 4A), this could indicate that different seasons could also render animals less or more susceptible to infections, since $24 \mathrm{ppt}$ water salinity is found during summers and 10 ppt during winters (Table I).

Table 1. Water salinity and $\mathrm{pH}$ at "Vitória" city mangrove area.

\begin{tabular}{lcc}
\hline Parameter & Season & Mangrove $^{\mathrm{a}}$ \\
\hline Salinity (ppt) & Summer & $10.00 \pm 0.60^{\mathrm{b}}$ \\
& Winter & $24.53 \pm 5.27^{\mathrm{c}}$ \\
$\mathrm{pH}$ & Summer & $7.2 \pm 0.2^{\mathrm{b}}$ \\
& Winter & $6.8 \pm 0,6^{\mathrm{c}}$ \\
\hline
\end{tabular}

${ }^{a}$ Parameters were measured during 2010-2011 in 4 different areas of a mangrove at "Vitória" city. Each value represents the average and standard deviation of 4 independent measurements.

${ }^{\mathrm{b}}$ Average values of salinity or $\mathrm{pH}$ during summers.

${ }^{c}$ Average values of salinity or $\mathrm{pH}$ during winters.

In conclusion, we observed that tide differences could interfere with hemocyte cell types inside $U$. cordatus hemolymph. Therefore, these animals would have different responses to pathogens according to such variations in their innate immune system. Taken together with other studies, our results show that improvement of husbandry conditions for animals under the influence of high environmental variations during the day should be used to observe physiological differences that occur in nature.

\section{ACKNOWLEDGMENTS}

We would like to thank Dr. Levy de Carvalho Gomes (Lab Peixe, Universidade Vila Velha, ES, Brazil) for landing fish tanks and equipments and Dr. David N. Olivieri for critical review of this manuscript. This work was partially supported by a FAPES grant (0461/2015).

\section{REFERENCES}

CONTI, R. C.; NALESSO, R. C. Status of the population structure of the mangrove crab Ucides cordatus (Decapoda: Ocypodidae) on the Piraquê-açu River estuary, Espírito Santo, Brazil. Braz. J. Oceanogr., v. 58, n. 2, p. 81-92, 2010.

CORRÊA JUNIOR, J. D.; ALLODI, S.; AMADO-FILHO, G. M.; FARINA, M. Zinc accumulation in phosphate granules of Ucides cordatus hepatopancreas. Braz. J. Med. Biol. Res., v. 33 , n. 2, p. $217-221,2000$.
DIELE, K.; KOCH, V.; SAINT-PAUL, U. Population structure, catch composition and CPUE of the artisanally harvested mangrove crab Ucides cordatus (Ocypodidae) in the Caeté estuary, North Brazil: Indications for overfishing? Aquat. Living Resour., v. 18, n. 2, p. 169-178, 2005.

GLASER, M.; DIELE, K. Asymmetric outcomes: assessing central aspects of the biological, economic and social sustainability of a mangrove crab fishery, Ucides cordatus (Ocypodidae), in North Brazil. Ecol. Econ., v. 49, n. 3, p. 361-373, 2004.

GOES, P.; BRANCO, J. O.; PINHEIRO, M. A. A.; BARBIERI, E.; COSTA, D.; FERNANDES, L. L. Bioecology of the uçá-crab, Ucides cordatus (Linnaeus, 1763), in Vitória Bay, Espírito Santo State, Brazil. Braz. J. Oceanogr., v. 58, n. 2, p. 153-163, 2010.

JOHANSSON, M. W.; KEYSER, P.; SRITUNYALUCKSANA, K.; SÖDERHÄLL, K. Crustacean haemocytes and haematopoiesis. Aquaculture, v. 191, n. 1-3, p. 45-52, 2000.

LEITE, M. M. L.; REZENDE, C. F.; SILVA, J. R. F. Population biology of the mangrove crab Ucides cordatus (Decapoda: Ucididae) in an estuary from semiarid Northeastern Brazil. Rev. Biol. Trop., v. 61, n. 4, p. 1721-1735, 2013.

LEITE, V. P.; ZANOTTO, F. P. Calcium transport in gill cells of Ucides cordatus, a mangrove crab living in variable salinity environments. Comp. Biochem. Physiol. P: A Mol. Integr. Physiol., v. 166, n. 2, p. 370-374, 2013.

MIGUEL, N. C. O.; WAJSENZON, I. J. R.; ANDRADE, L. R.; TORTELOTE, G. G.; EINICKER-LAMAS, M.; ALLODI, S. Catalase, Bax and p53 expression in the visual system of the crab Ucides cordatus following exposure to ultraviolet radiation. Cell Tissue Res., v. 329, n. 1, p. 159-168, 2007.

MILLAR, D. A.; RATCLIFFE, N. A. Invertebrates. In: TURNER, R. J. (Ed.). Immunology: A Comparative Approach. New York: Wiley, 1994. p. 29-68.

NORDHAUS, I.; WOLFF, M. Feeding ecology of the mangrove crab Ucides cordatus (Ocypodidae): food choice, food quality and assimilation efficiency. Mar. Biol., v. 151, n. 5, p. 16651681, 2007.

ORÉLIS-RIBEIRO, R.; BOEGER, W. A.; VICENTE, V. A.; CHAMMAS, M.; OSTRENSKY, A. Fulfilling Koch's postulates confirms the mycotic origin of Lethargic Crab Disease. Antonie Van Leeuwenhoek, v. 99, n. 3, p. 601-608, 2011.

PASSOS, C. A.; DI BENEDITTO, A. P. M. Captura comercial do caranguejo-uçá, Ucides cordatus (L., 1763), no Manguezal de Gargaú, RJ. Biotemas, v. 18, n. 1, p. 223-231, 2005.

PIE, M. R.; BOEGER, W. A.; PATELLA, L.; VICENTE, V. A.; RIBEIRO, R. O.; OSTRENSKY, A. Specific primers for the detection of the black-yeast fungus associated with lethargic crab disease (LCD). Dis. Aquat. Organ., v. 94, n. 1, p. 73-75, 2011.

PINHEIRO, M. A.; SILVA, P. P.; DUARTE, L. F.; ALMEIDA, A. A.; ZANOTTO, F. P. Accumulation of six metals in the mangrove crab Ucides cordatus (Crustacea: Ucididae) and its food source, the red mangrove Rhizophora mangle (Angiosperma: Rhizophoraceae). Ecotoxicol. Environ. Saf., v. 81, p. 114-121, 2012.

SANT'ANNA, B. S.; BORGES, R. P.; HATTORI, G. Y., PINHEIRO, M. A. A. Reproduction and management of the mangrove crab Ucides cordatus (Crustacea, Brachyura, Ucididae) at Iguape, São Paulo, Brazil. An. Acad. Bras. Ciênc., v. 86, n. 3, p. 1411-1421, 2014. 
SANTOS, M. D. C. F. Drinking and osmoregulation in the mangrove crab Ucides cordatus following exposure to benzene. Comp. Biochem. Physiol. P: A Mol. Integr. Physiol., v. 133, n. 1, p. 29-42, 2002.

SCHORIES, D.; BERGAN, A. B.; BARLETTA, M.; KRUMME, U.; MEHLIG, U.; RADEMAKER, V. The keystone role of leaf-removing crabs in mangrove forests of North Brazil. Wetl. Ecol. Manag., v. 11, n. 4, p. 243-255, 2003.

SMITH, V.; SÖDERÄLL, K. Induction of degranulation and lysis of haemocytes in the freshwater crayfish, Astacus astacus by components of the prophenoloxidase activating system in $v i$ tro. Cell Tissue Res., v. 233, n. 2, p. 295-303, 1983.

SÖDERHÄLL, K.; CERENIUS, L. Crustacean immunity. Annu. Rev. Fish Dis., v. 2, p. 3-23, 1992.
VICENTE, V. A.; ORÉLIS-RIBEIRO, R.; NAJAFZADEH, M. J.; SUN, J.; GUERRA, R. S.; MIESCH, S.; OSTRENSKY, A.; MEIS, J. F.; KLAASSEN, C. H.; DE HOOG, G. S; BOEGER, W. A. Black yeast-like fungi associated with Lethargic Crab Disease (LCD) in the mangrove-land crab, Ucides cordatus (Ocypodidae). Vet. Microbiol., v. 158, n. 1-2, p. 109122, 2012.

VIEIRA, R. H. F.; LIMA, E. A.; SOUSA, D. B. R. S.; REIS, E. F.; COSTA, R. G.; RODRIGUES, D. P. Vibrio spp. and Salmonella spp., presence and susceptibility in crabs Ucides cordatus. Rev. Inst. Med. Trop. Sao Paulo, v. 46, n. 4, p. 179-182, 2004.

VILHENA, M. S. P.; COSTA, M. L.; BERREDO, J. F. Accumulation and transfer of $\mathrm{Hg}$, As, Se, and other metals in the sediment-vegetation-crab-human food chain in the coastal zone of the northern Brazilian state of Pará (Amazonia). Environ. Geochem. Health, v. 35, n. 4, p. 477-494, 2013. 